\title{
A comparison of single phase standalone square waveform solar inverter topologies: Half bridge and full bridge
}

\author{
Aicha Chemseddine ${ }^{1}$, Noureddine Benabadji ${ }^{2}$, Ali Cheknane ${ }^{3}$, Salah Eddine Mankour ${ }^{4}$ \\ ${ }^{1,2}$ Laboratory of Analysis and Application of Radiation, \\ University of Science and Technology Mohamed Boudiaf, Algeria \\ ${ }^{3}$ Laboratory of Semiconductor and Functional Materials, Amar Tlidji University, Algeria \\ ${ }^{4}$ Department of Electrical Engineering, University of Science and Technology Mohamed Boudiaf, Algeria
}

\begin{tabular}{l}
\hline Article Info \\
\hline Article history: \\
Received Apr 10, 2019 \\
Revised Jan 12, 2020 \\
Accepted Feb 2, 2020 \\
\hline
\end{tabular}

Keywords:

Boost converer

Full bridge inverter

Half bridge inverter

Photovoltaic inverter

Stand-alone installation

\section{Corresponding Author:}

Aicha Chemseddine,

Département de Physique,

Laboratoire d'analyse et d'application des rayonnements (LAAR),

Université des Sciences et de la Technologie d'Oran Mohamed Boudiaf,

BP 1505, El M'naouer, 31000 Oran Algérie.

Email: aicha.chemseddine@univ-usto.dz

\section{INTRODUCTION}

With the revolution and the advance of the use of photovoltaic installations all around the word, many designs and conceptions of photovoltaic devices have been developed [1-3], especially the conception and the design of DC-DC and DC-AC converters circuits [4-6]. Because of the low efficiency and the high cost of solar modules in photovoltaic systems [7], the effiecicy and the cicuits simplicity of the other devices of photovoltaic system have to be the most higher possible. A Stand-alone photovoltaic installation is an off grid installation, in which the photovoltaic modules are the only source that generates the electric power to feed a DC or an AC load [8]. Photovoltaic modules generate a DC electric power thus to feed an AC load in stand-alone photovoltaic installation a stand-alone photovoltaic inverter has to be used to convert the DC power produced by the photovoltaic modules into an AC power [9-12].

Depending on the shape of the AC output voltage generated by the inverter there exist three main types of single phase stand-alone photovoltaic inverters: pure sinewaveform inverters, modulated waveform inverters and square waveform inverters [13-15] and each type of these inverters is also divided into different topologies: half bridge and full bridge for the square waveform inverters and multilevel (bridges) for the modulated waveform and the pure sinewave inverters. Square waveform inverters are designed to feed loads which have an important inductance [6] as motors because inductive loads allow having relatively pure sinewave current. Looking for the most efficient and the simplest cicuit design of stand alone single phase solar inveter to feed AC motors and inductive loads, in this paper we will be interested by the square waveform single phase inverters doing a comparative study of the efficiency and the simplicity between the half bridge and full bridge topologies simulating them on ISIS Proteus software. 


\section{HALF BRIDGE SQUARE WAVEFORM SOLAR INVERTER CIRCUIT}

Figure 1 presents a single phase half bridge square waveform photovoltaicinverter which is composed of two stages: dc-dc and dc-ac stage. The dc-dc stage is a boost converter which is used to convert the low voltages produced by the PV modules (12-24V) into V 440 to have an RMS voltage value equal to $220 \mathrm{~V}$ by the half bridge inverter. The output of the boost converter is connected in parallel with tow capacitors dividers to get $V_{\text {out }}=V_{b} / 2$ when $: S_{2}$ is on and $S_{3}$ is off and get $V_{\text {out }}=-V_{b} / 2$ when $S_{3}$ is on and $S_{2}$ is off [16-20]. The swiches of this topology would be driven by simple square pulses.

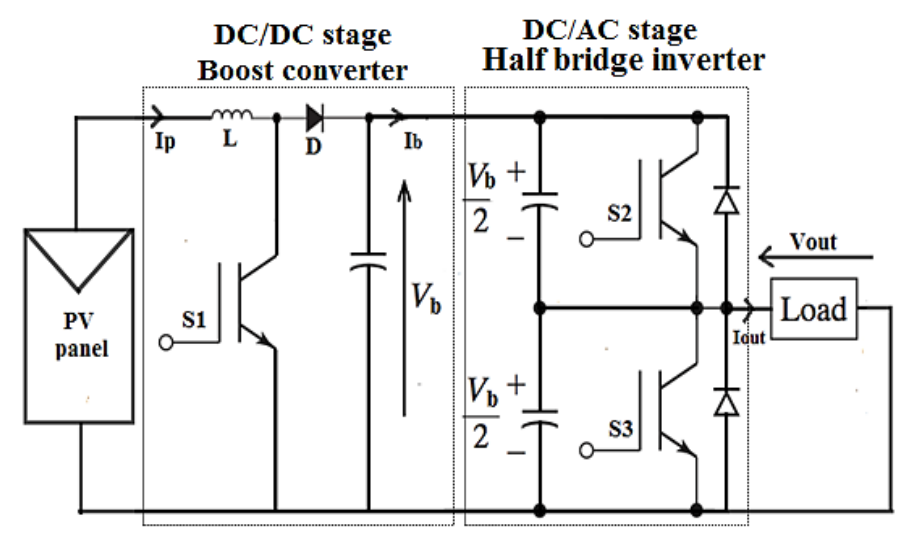

Figure 1. Single phase half bridge square waveform inverter stages

\section{FULL BRIDGE SQUARE WAVEFORM SOLARINVERTER CIRCUIT}

Figure 2 presents a single phase full bridge square waveform solar inverter which is also composed of two stages as the half bridge one: a dc-dc and a dc-ac stage. The dc-dc stage is a boost converter which is used to convert the low voltages produced by the PV modules (12-24V) into a Vdc equal to 220 to have an RMS voltage value equal to $220 \mathrm{~V}$ by the full bridge inverter. The output of the boost converter is connected in parallel with two legs and each leg is composed of two inverting switches connected in series. The output voltage of the inverter equal to $V_{b}$ when $S_{2}$ and $S_{5}$ are on and $S_{3}$ and $S_{4}$ are off and equal to $-V_{b}$ when $S_{3}$ and $S_{4}$ are on and $S_{2}$ and $S_{5}$ are off [21-25]. The swiches would be driven by simple square pulses.

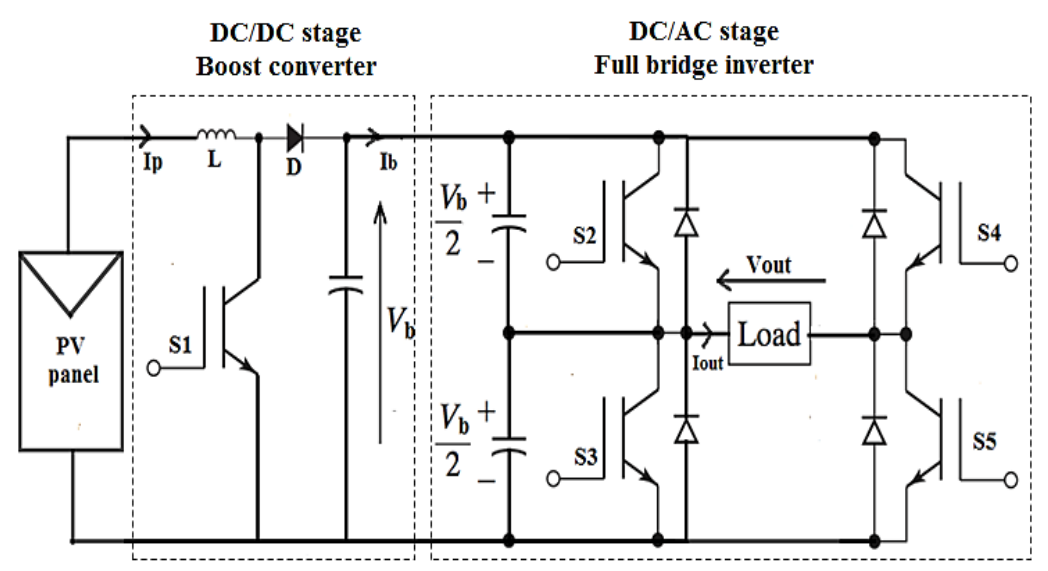

Figure 2. Single phase half bridge square waveform inverter stages

\section{DESIGN OF THE BOOST CONVERTER}

Figure 3 shows the basic configuration of a boost converter, its composed of an inductor, a switch: IGBT or a MOSFET transistor, a diode and a capacitor. In this part of the paper we will presents how to size and calculate the parameters of each one of its components which depend on the output voltage and current [26-28]. 


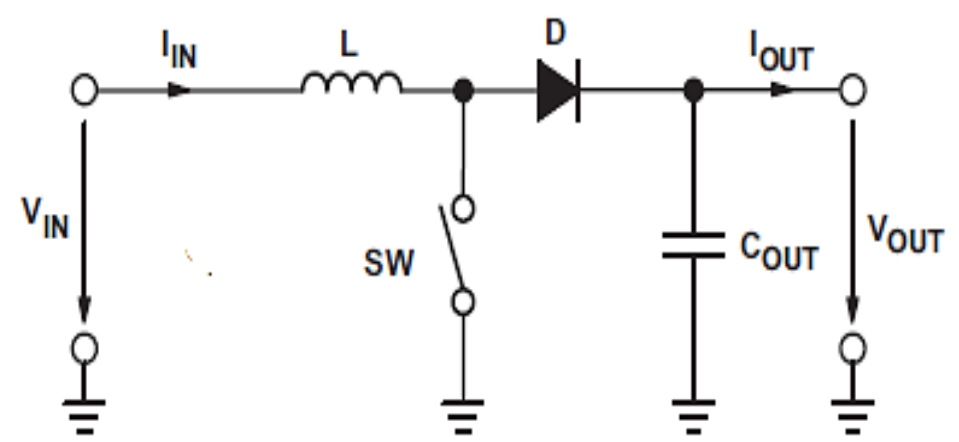

Figure 3. The boost converter power stage [26].

\subsection{Duty cycle}

$$
D=1-\frac{V_{I N}}{V_{\text {OUT }}} \times \eta
$$

Where,

$V_{I N}$ : Is the voltage coming from the PV module which is equal to $12 \mathrm{~V}$ or $24 \mathrm{~V}$.

$V_{\text {OUT }}$ : Is the desired voltage 220 for the full bridge inverter and $440 \mathrm{~V}$ for the half bridge one. $\eta$ : The inverter efficiency.

\subsection{Inductor selection}

Equation 2 [26] presents a good estimation for the right inductor:

$$
L=\frac{V_{I N} \times\left(V_{\text {OUT }}-V_{I N}\right)}{\Delta l_{l} \times f_{S} \times V_{O U T}}
$$

Where,

$\Delta l_{l}$ : The estimated inductor ripple current, a good estimation for the inductor ripple current is $20 \%$ to $40 \%$ of the output current.

$f_{S}$ : Minimum switching frequency of the converter.

\subsection{Inductor ripple current}

The inductor ripple current is calculated by the expression [26]:

$$
\Delta l_{l}=(0.2 \text { to } 0.4) \times I_{O U T(M A X)}
$$

Where,

$I_{\text {OUT(MAX) }}$ : The maximum output current.

\subsection{Output capacitor selection}

Capacitors are used to minimize the ripple on the output voltage. The following equation can be used to adjust the output capacitor values for a desired output voltage ripple [26]:

$$
C_{\text {OUT (MIN) }}=\frac{I_{\text {OUT }(M A X)} \times D}{f_{S} \times \Delta V_{\text {OUT }}}
$$

\section{SIMULATION PROCEDURES}

In this part two stand-alone square waveform inverters topologies have been simulated on ISIS Proteus software: a half and a full bridge inverter. Each one of them has been designed to deliver an output power equal to 1000 wat and an output voltage equal to $220 \mathrm{~V}$ with $50 \mathrm{HZ}$ of frequency. The PWMs used to control the circuit switches have been generated and controlled by the PIC 16F877A. 


\subsection{The half bridge inverter circuit description}

This inverter is composed of two stages: a dc-dc and a dc-ac stage as shown in Figure 4. The dc-dc stage Figure 5 is a boost converter that converts the panel voltage $\mathrm{Vp}=24 \mathrm{~V}$ into $\mathrm{Vb}=440 \mathrm{~V}$. An IGBT (IRG4PC50S) is used as a switch controlled by the PIC 16F877A and the IR211 driver. The output of the boost converter is connected in parallel with tow capacitors connected in series and a leg of two IGBTs (IRG4PC50KD) connected also in seriesto get an output voltage $\mathrm{Vo}=\mathrm{Vb} / 2=220 \mathrm{~V}$ when $\mathrm{t}=\mathrm{T} / 2$ and $\mathrm{Vo}=-\mathrm{Vb} / 2=-220$ when $\mathrm{t}=\mathrm{T}$ Figure 6 . Table 1 presents the boost parameters, they were determined using the (1-4).

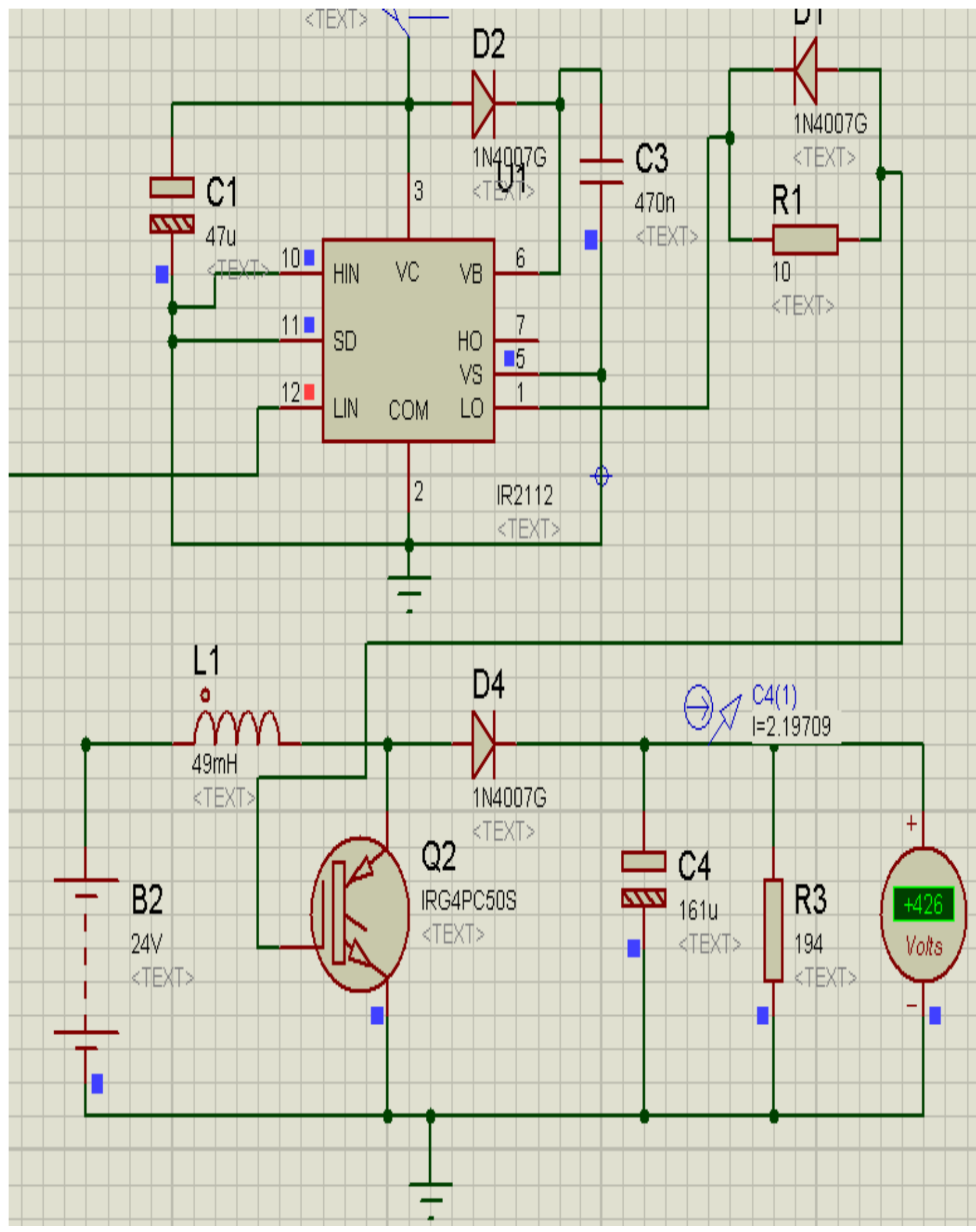

Figure 4. The boost simulated circuit of the half bridge inverter 


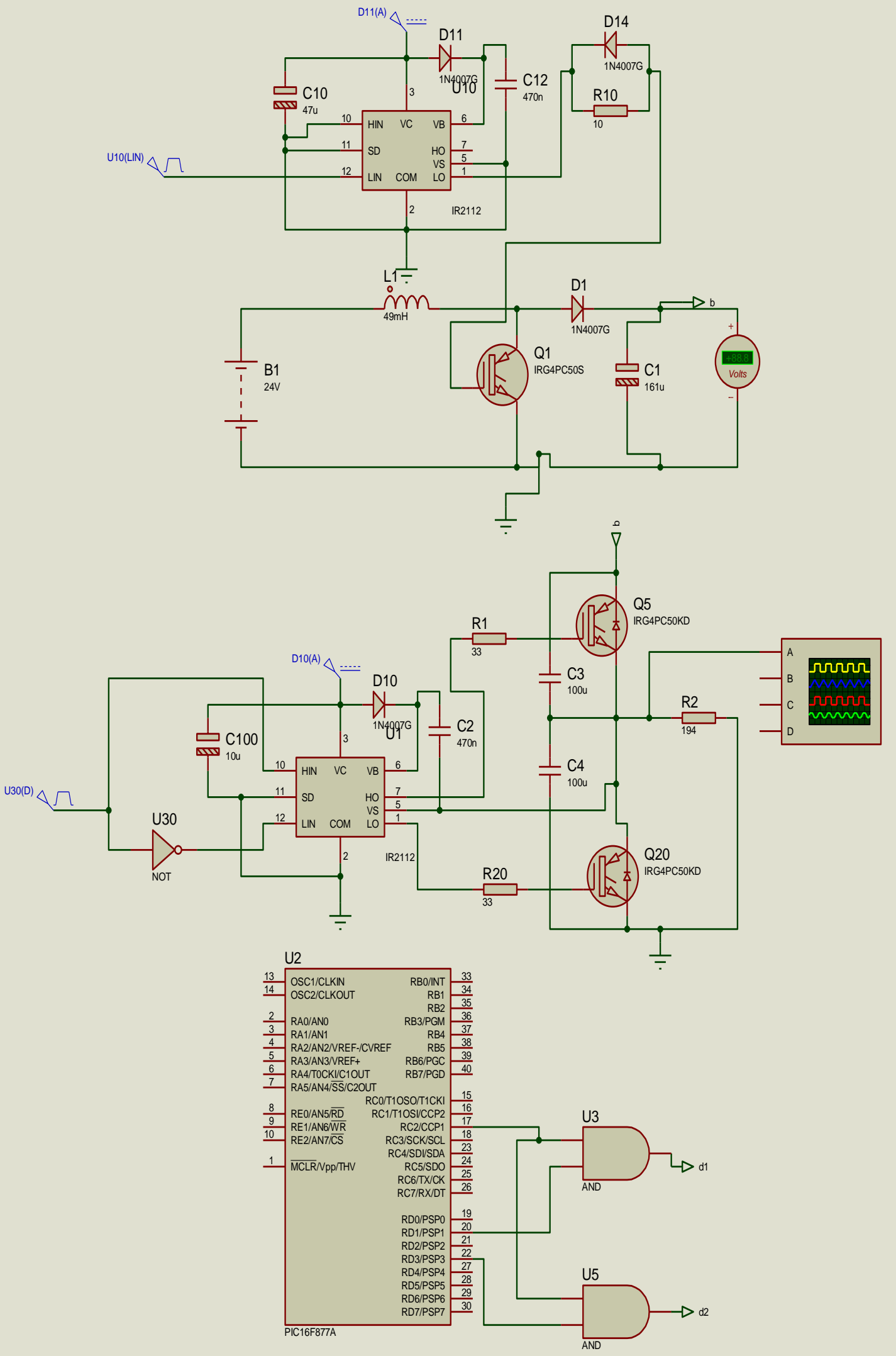

Figure 5 . The haf bridge inverter simulated circuit 


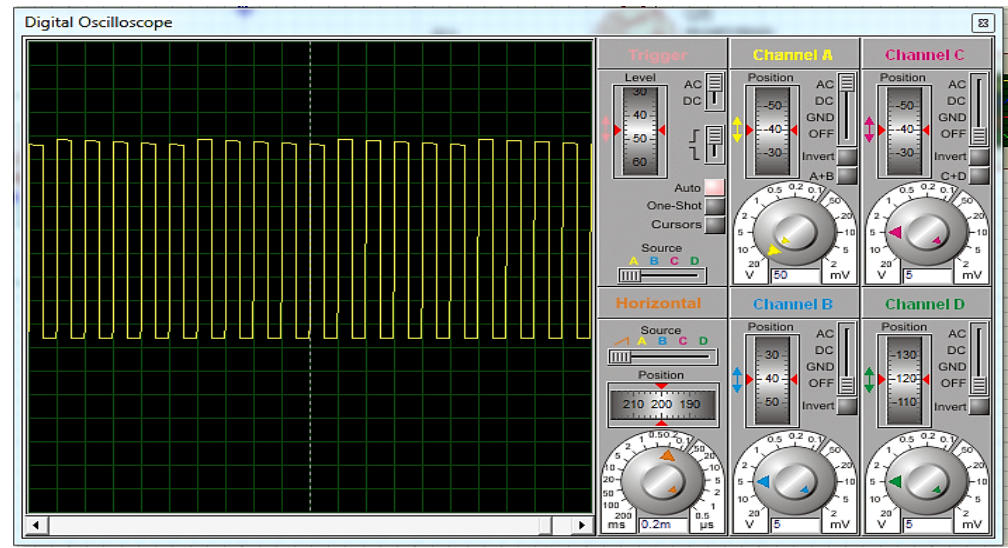

Figure 6. Theoutput voltageofthe half bridge inverter

Table 1. Boost converter parameters of the half bridge inverter

\begin{tabular}{lcc}
\hline Parameters & Symbol & Value \\
\hline Duty cycle & $\mathrm{D}$ & 0.94 \\
Minimum switching frequency of the converter & $f_{S}$ & $1 \mathrm{kHz}$ \\
Desired inductor ripple current $(20 \%$ of the output current) & $\Delta l_{L}$ & 0.454 \\
Desired output voltage ripple $(3 \%$ of output voltage $)$ & $\Delta V_{\text {OUT }}$ & $13.2 \mathrm{~V}$ \\
Maximum output current $\left(V_{\text {OUT }} / R\right)$ & $I_{\text {OUT }}$ & $2.27 \mathrm{~A}$ \\
\hline
\end{tabular}

\subsection{The full bridge inverter circuit description}

This inverter is also composed of two stages: a dc-dc and a dc-ac as shown in Figure 7 .The dc-dc stage Figure 8 is a boost converter that converts the panel voltage $\mathrm{Vp}=24 \mathrm{~V}$ into $\mathrm{Vb}=220 \mathrm{~V}$. An IGBT (IRG4PC50S) is used as a switch controlled by the IR211 driver. The output of the boost converter is connected in parallel with two capacitors in series and two legs, each leg contains two IGBTs (IRG4PC50KD) in series to give an output voltage $\mathrm{Vo}=(+\mathrm{Vb} / 2+\mathrm{Vb} / 2=+\mathrm{Vb}=220 \mathrm{~V})$ when $\mathrm{t}=\mathrm{T} / 2$ and $\mathrm{Vo}=(-\mathrm{Vb} / 2-\mathrm{Vb} / 2=-\mathrm{Vb}=-220 \mathrm{~V})$ when $\mathrm{t}=\mathrm{T}$. Table 2 presents the Boost converter parameters of the full bridge inverter.

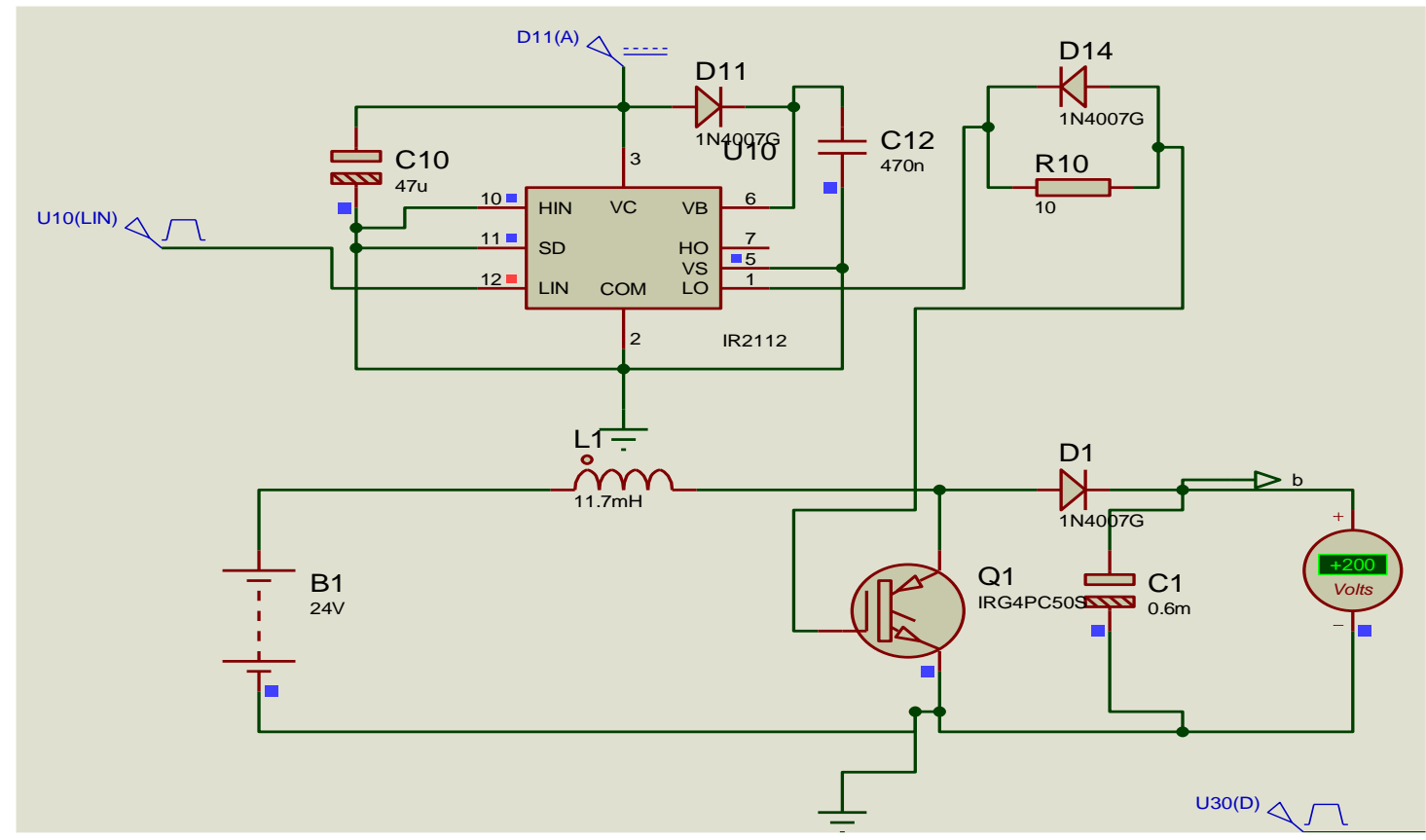

Figure 7. The boost simulated circuit of the full bridge inverter 


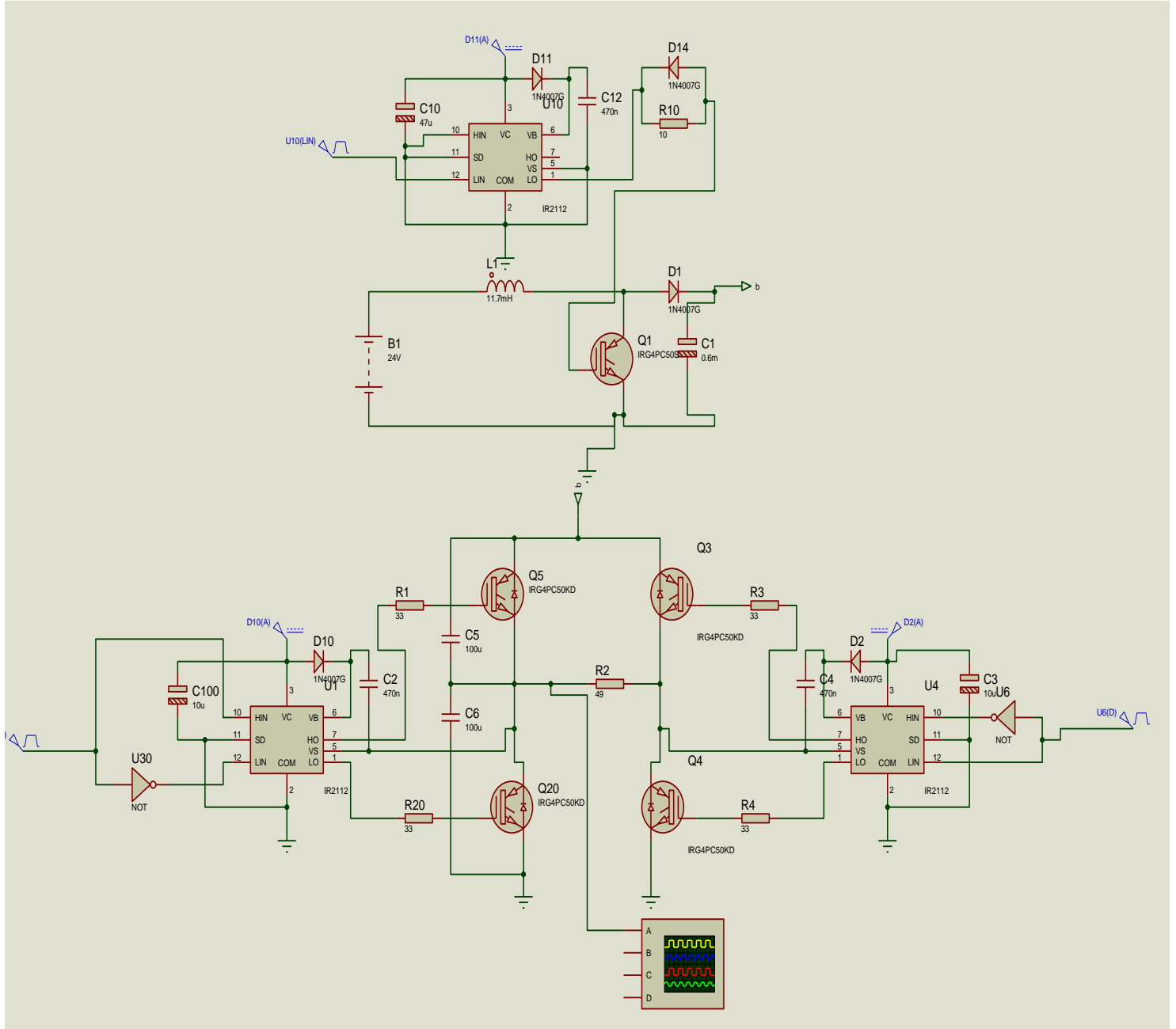

Figure 8 . The full bridge inverter simulated circuit

Table 2. Boost converter parameters of the full bridge inverter

\begin{tabular}{lcc}
\hline Parameters & Symbol & Value \\
\hline Duty cycle & $\mathrm{D}$ & 0.89 \\
Minimum switching frequency of the converter & $f_{S}$ & $1 \mathrm{kHz}$ \\
Desired inductor ripple current $(20 \%$ of the output current) & $\Delta l_{L}$ & 0.908 \\
Desired output voltage ripple $(3 \%$ of output voltage) & $\Delta V_{\text {OUT }}$ & $6.6 \mathrm{~V}$ \\
Maximum output current $\left(V_{\text {OUT }} / R\right)$ & $I_{\text {OUT }}$ & $4.54 \mathrm{~A}$ \\
\hline
\end{tabular}

\section{SIMULATION RESUTS AND COMPARISON}

As presented in Figues 4 and 7, the output voltages of boost converters are different: 220V for the one used in the full bridge inverter and $440 \mathrm{~V}$ for that one used in the half bridge inverter that make theircomponents parameters different using the same switching frequency and the input voltage, the main differences between the two inverters cited in the points below indicate that the half bridge inverter has less conduction losses than the full bridge inverter, due to the high output voltage of its boost converter, whereas, this high voltage could makes a risk on operators and the system, that leads to the use of an important isolation. Also the half bridge inverter has a simpler circuit design than the full bridge inverter wich reduces the cost and the time of asemblage

\subsection{Desired output voltage ripple}

As shown in Figures 9 and 10 the output voltage ripple of the boost converter used in half bridge inverter is more important than that of full bridge output voltage ripple they are the double because $3 \%$ of $220 \mathrm{~V}$ equal to 6.6 and $3 \%$ of $440 \mathrm{~V}$ equal to 13.2 . 


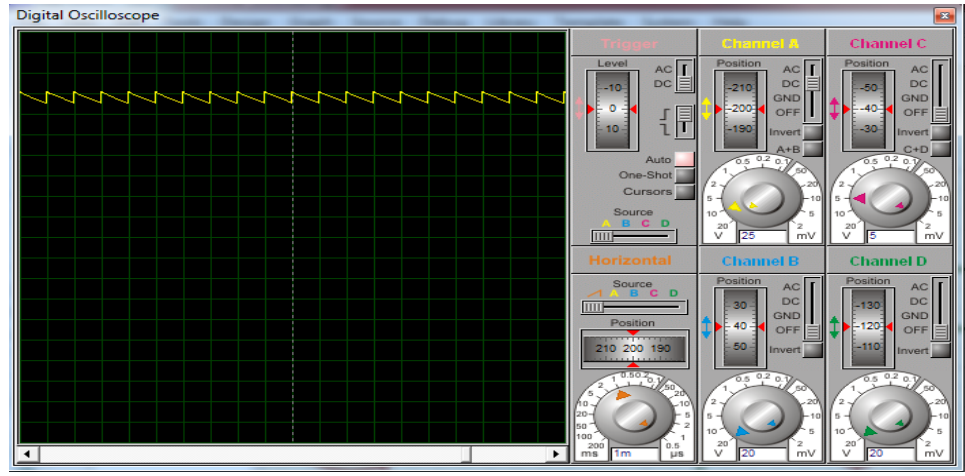

Figure 9.The boost converter output voltage used in the half bridge inverter

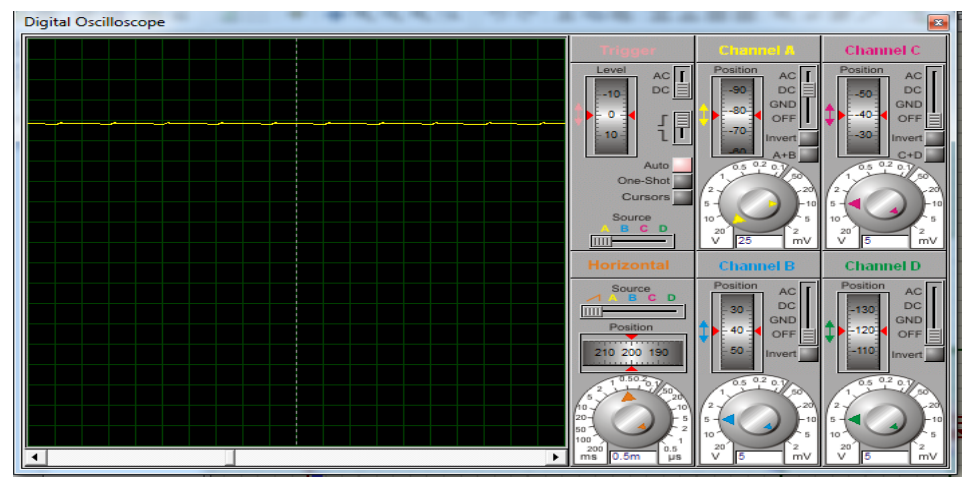

Figure 10.The boost converter output voltage used in the full bridge inverter

\subsection{The output voltage in the half bridge inverter}

As has been sized, the boost converter of the half bridge inverter has to deliver an output voltage equal to $440 \mathrm{~V}$ this high voltage could be a risk on operators and the system which leads to the use of an important isolation, however,the advantage of this topology voltage is to reduce the current following the IGBTs into the half and by consequently the conduction losses in the IGBTs with $50 \%$ (200\% less than that in the IGBTs of the full bridge inverter).

\subsection{Duty cycle and conduction losses}

As presented in Tables 1 and 2 the duty cycle of the boost used in the half bridge inverter topology is higher than that used in the full bridge topology with $5 \%$ (10\% higher than a full bridge inverter) that enhances the conduction losses in the IGBT with the same amount, because the conduction losses are present during the period of the duty cycle $[15,19]$.

\subsection{The boost inductor and output capacitor}

As shown in Table 1, the boost converter used in the full bridge inverter topology has a higher capacitor capacitancethan that one used in the half bridge inverter topology but the contrary for the inductor inductance: the boost converter used in the half bridge inverter has a higher inductor inductance than that one of the full bridge converter.

\subsection{The component number}

The full bridge inverter contains more components than the half bridge inverter due to the presence of one more leg of switches which makes its circuit more complex. Also the production cost of the full bridge inverter is higher than that of half bridge inverter because of the time and the effort of the assemblage.

\section{CONCLUSION}

In this paper a comparative study between tow topologies of stand-alone square waveform photovoltaic inverters has been done, simulating them on ISIS Proteus software. This study shows that the pefomance and the simplicity of half bridge inverter are higher than those of full bidge inveter wich make it the best solution in stand alone photovoltaic insallations that feed inductive loads and motors. 


\section{REFERENCES}

[1] A. Mezouari, et al., "A New Photovoltaic Energy Sharing System between Homes in Standalone Areas," Int. J. of Electrical and Computer. Engineering, vol. 8, no. 6, pp. 4855-4862, 2018.

[2] H. Fathabadi, "Novel High Efficiency DC/DC Boost Converter for using in Photovoltaic Systems," Solar Energy, vol. 125, pp. 22-31, 2016.

[3] R. Palanisamy, et al., "Simulation of Various DC-DC Converters for Photovoltaic System," Int. J. of Electrical and Computer. Engineering, vol. 9, pp. 917-925, 2019.

[4] J. Q. Wang, and J. X. Li, "Design and Experience of Grid-Connecting Photovoltaic Power System," IEEE International Conference on Sustainable Energy Technologies, pp. 607-610, 2008.

[5] S. Shanmugasundaram, "Solar Based Z Source Inverter for High Power Application," Bulletin of Electrical Engineering and Informatics, vol. 6, no. 4, pp. 343-347, 2017.

[6] Y. P. Siwakoti, and F. Blaabjerg. "Common-Ground-Type Transformerless Inverters for Single-Phase Solar Photovoltaic Systems," IEEE Transactions On Industrial Electronics, vol. 65, pp. 2100-2111, 2018.

[7] A. Suzdalenko, and A. Chub, "Current Sensorless Control for Half-Bridge based AC/DC PFC Converter with Consideration of Conduction Losses," Int. J. OF Circuit Theory And Applications, vol. 44, pp. 2072-2084, 2016.

[8] L. Zhang, et al., "A Family of Neutral Point Clamped Full-Bridge Topologies for Transformerless Photovoltaic Grid-Tied Inverters," IEEE Transactions ON Power Electronics, vol. 28, pp.730-738, 2013.

[9] H. F. Xiao, K. Lan, and L. Zhang, "A Quasi-Unipolar SPWM Full-Bridge Transformerless PV Grid-Connected Inverter with Constant Common-Mode Voltage," IEEE Transactions ON Power Electronics, vol. 30, no. 6, pp. 3122-3131, 2015.

[10] B. Hauke, "Basic Calculation of a Boost Converter's Power Stage," Application Repport, pp. 1-8, 2014.

[11] R. Langella, "Experimental-Based Evaluation of PV Inverter Harmonic and Interharmonic Distortion Due to Different Operating Conditions," IEEE Transactions On Instrumentation And Measurement, vol. 65, no. 10, pp. 2221-2293, 2016.

[12] Y. Shi, et al, "A $60 \mathrm{~kW} 3 \mathrm{~kW} / \mathrm{kg}$ 5-Level T-Type SiC PV Inverter with 99.2\% Peak Efficiency," IEEE Transactions ON Industrial Electronics, vol. 64, no. 11, pp. 9144-9154, 2017.

[13] N. Prabaharan, and K. Palanisamy, "Analysis and Integration of Multilevel Inverter Configuration with Boost Converters in a Photovoltaic System," Energy Conversion and Management, vol. 128, pp. 327-342, 2016.

[14] D. Barater, et al., "Recent Advances in Single-Phase Transformerless Photovoltaic Inverters," IET Renewable Power Generation, vol. 10, no. 2, pp. 260-273, 2016

[15] Y. Xia, J. Roy and R. Ayyanar, "A Capacitance-Minimized, Doubly Grounded Transformer less Photovoltaic Inverter With Inherent Active-Power Decoupling," IEEE Transactions on Power Electronics, vol. 32, no. 7, pp. 5188-5201, 2017.

[16] X. Guo, and X. Jia, "Hardware-Based Cascaded Topology and Modulation Strategy With Leakage Current Reduction for Transformerless PV Systems," IEEE Transactions on Industrial Electronics, vol. 63, no. 63, pp. 7823-7832, 2016.

[17] Y. R. Kafle, et al., "Performance Comparison of Single-Phase Transformerless PV Inverter System," IEEE Applied Power Electronics Conference and Exposition, pp. 3589-3593, 2017.

[18] H. I. Eini, S. Bacha, and D. Frey, "Improved Control Algorithm for Grid-Connected Cascaded H-Bridge Photovoltaic Inverters Under Asymmetric Operating Conditions," IET Power Electronics, vol. 11, no. 3, pp. 407-415, 2018.

[19] P. Saadat, and K. Abbaszadeh, "A Single-Switch High Step-Up DC-DC Converter Based on Quadratic Boost," IEEE Transactions on Industrial Electronics, vol. 63, no. 12, pp. 7733-7742, 2016.

[20] R. O. C'aceres, and I. Barbi, "A Boost DC-AC Converter: Analysis, Design, and Experimentation," IEEE Transactions On Power Electronics, vol. 14, no. 1, pp. 134-141, 1999.

[21] T. Selmi, and M. Rezgui, "A Novel DC-AC Inverter Topology to Eliminate Leakage Current," International Journal of Power Electronics and Drive System, vol. 9, no. 4, pp. 1733-1744, 2018.

[22] M. A. N. Doss, et al., "Photovoltaic Fed Multilevel Inverter using Reverse Voltage Topology for Standalone Systems," International Journal of Power Electronics and Drive System, vol. 10, no. 3, pp. 1347-1354, 2019.

[23] M. J. Fadhil, R. A. Fayadh, and M. K. Wali, "Design and Implementation of Smart Electronic Solar Tracker based on Arduino," TELKOMNIKA, vol. 17, no. 5, pp. 2486-2496, 2019.

[24] I. Yadav, S. K. Maurya, and G. K. Gupta, "A Literature Review on Industrially Accepted MPPT Techniques for Solar PV System," Int. J. of Electrical and Computer Engineering, vol. 10, no. 2, pp. 2117-2127, 2020.

[25] S. I. Sulaiman, and N. A. Ali, "Performance Simulation of the Integration of Hybrid Stand-Alone Photovoltaic System at Tuba Island," Indo. J. of Electrical Enginee. and Comp. Sci., vol. 16, no. 1, pp. 107-115, 2019.

[26] Akinwole OO, "Design and Simulation of a 1kVA Arduino Microcontroller Based Modified Sine Wave Inverter Using Proteus," Journal of Electrical \& Electronic Systems, vol. 7, no. 4, pp. 1-5, 2018.

[27] Nilam Rathod, Anjali Sharma, Uvaish Mansur, MiteshKumar Priyadarshi, "Design \& Simulation of a 100W Pure Sine Wave Inverter Using IC CD4047," International Journal of Scientific Research in Science and Technology, vol. 4, no. 5, pp. 675-678, 2018.

[28] H. Radwan, "A Novel Single-Stage High-Frequency Boost Inverter for PV Grid-Tie Applications," IEEE Applied Power Electronics Conference and Exposition, pp. 2417-2423, 2018. 